\title{
POLA ASUH MAKAN KAITANNYA DENGAN DERAJAT STUNTING PADA ANAK BALITA DI KABUPATEN INDRAMAYU
}

\author{
Tayong Siti Nurbaeti ${ }^{1}$, Eko Maulana Syaputra ${ }^{2}$ \\ ${ }^{1,2}$ Universitas wiralodra, Jln. Ir. H. Juanda Km 3, Indramayu’t.siti.nurbaeti@gmail.com, \\ ekomaualanasyaputra.unwir.ac.id
}

Diterima 20 September 2020, disetujui 31 Oktober 2020, diterbitkan 30 Oktober 2020

Pengutipan: Nurbaeti, T.S \& Syaputra, E.M (2020). Pola Asuh Makan Kaitannya dengan Derajat Stunting Pada Anak Balita di Kabupaten Indramayu. Gema Wiralodra, Vol 11, No 2, Hal 311-318, Oktober 2020

\begin{abstract}
ABSTRAK
Stunting merupakan gangguan pertumbuhan linear yang disebabkan oleh malnutrisi kronis, yang dinyatakan dengan nilai z-skor tinggi badan menurut umur (TBU) berdasarkan standar yang ditetapkan oleh World Health Organization. Penelitian ini ditujukan untuk menganalisis pola asuh makan dengan derajat stunting pada anak balita di Kabupaten Indramayu. Penelitian ini dilakukan di dua belas desa yang ada di Kabupaten Indramayu yang terdiri dari desa Balongan, Rawadalem, Sudimampir Lor, Tegalurung, Pringgacala, Lemah Ayu, Tenajar Kidul, Kalianyar, Tunggul Payung, Kiajaran Wetan, Totoran, dan Kerticala. Jenis penelitian analitik dengan desain cross sectional. Sampel dalam penelitian adalah 400 anak balita yang stunting di Kabupaten Indramayu. Analisis data menggunakan uji Chi Square. Hasil penelitian menemukan bahwa pola asuh makan terbukti berhubungan dengan derajat stunting pada anak balita di Kabupaten Indramayu. Kesimpulan dari penelitian ini adalah pola asuh makan mempunyai pengaruh terhadap derajat stunting anak balita.
\end{abstract}

Kata Kunci : Pola Asuh Makan, Derajat Stunting.

\begin{abstract}
Stunting is a linear growth disorder caused by chronic malnutrition, which is expressed by the $\mathrm{z}$ score for height for age (TBU) based on the standards set by the World Health Organization. This study was aimed at analyzing eating patterns with the degree of stunting in children under five in Indramayu Regency. This research was conducted in twelve villages in Indramayu Regency which consisted of Balongan, Rawadalem, Sudimampir Lor, Tegalurung, Pringgacala, Lemah Ayu, Tenajar Kidul, Kalianyar, Tunggul Payung, Kiajaran Wetan, Totoran, and Kerticala villages. This type of analytic research with cross sectional design. The sample in the study was 400 children under five who were stunting in Indramayu Regency. Data analysis using Chi Square test. The results of the study found that eating patterns was proven to be related to the degree of stunting in children under five in Indramayu Regency. The specific objective of this research is to analyze the effect of food parenting with the degree of stunting in Indramayu Regency. The urgency in this study is the importance of proper and correct dietary care, so that it is hoped that in the future there will be no more children affected by stunting.
\end{abstract}

Keywords : Eating patterns, Stunting severity

\section{PENDAHULUAN}

Stunting merupakan gangguan pertumbuhan linear yang disebabkan oleh malnutrisi kronis, yang dinyatakan dengan nilai z-skor tinggi badan menurut umur 
(TBU) kurang dari -2 Simpangan Baku (SB) berdasarkan standar yang ditetapkan oleh World Health Organization (Jafar, 2012).Anak stunting cenderung sulit mencapai potensi pertumbuhan dan perkembangan optimal secara fisik maupun psikomotorik yang erat kaitannya dengan kemunduran kecerdasan dan produktivitas (WHO, 2010)

Balita yang mengalami stunting memiliki risiko terjadinya penurunan kemampuan intelektual, produktivitas, dan peningkatan risiko penyakit degeneratif di masa mendatang. Hal ini dikarenakan anak stuntingjuga cenderung lebih rentan terhadap penyakit infeksi, sehingga berisiko mengalami penurunan kualitas belajar di sekolah dan berisiko lebih sering absen. Stunting juga meningkatkan risiko obesitas, karena orang dengan tubuh pendek berat badan idealnya juga rendah. Kenaikan berat badan beberapa kilogram saja bisa menjadikan Indeks Massa Tubuh (IMT) orang tersebut naik melebihi batas normal. Keadaan overweight dan obesitas yang terus berlangsung lama akan meningkatan risiko kejadian penyakit degenerative (Purwadini, 2013)

Lingkungan yang buruk seperti sanitasi, air minum dan kepadatan penduduk juga menjadi peyebab anak stunting di kawasan kumuh Jakarta, dikarenakan perilaku tidak sehat akibat pengetahuan kesehatan yang rendah. Anak yang mengalami stunting ketika tidak segera di kejar pertumbuhannya saat usia 67 tahun akan berakibat fatal terhadap produktifitasnya dimasa dewasa (Paulo, 2000)

Berdasarkan riset kesehatan dasar prevalensi stunting di Indonesia pada tahun 2013 sebanyak 37,2\% dan pada tahun 2018 sebanyak 30,8\%. Meskipun mengalami penurunan namun angka tersebut masih tergolong tinggi jika dibandingkan dengan jumlah penduduk di Indonesia (Riskesdas, 2018)Jawa Barat angka stunting pada tahun 2018 yaitu 29,2 \%. Di Kabupaten Indramayu prevalensi stunting lebih tinggi dari prevalensi stunting di Jawa Barat yaitu 29.9 $\%$ (Profil Dinkes Indramayu, 2018)

Penelitian terkait pola asuh makan dan kejadian stunting belum banyak dilakukan khususnya di Kabupaten Indramayu. Berdasarkan hal tersebut maka penelitian ini adalah untuk menganalisis pengaruh pola asuh makan dengan derajat stunting di Kabupaten Indramayu. Urgensi dalam penelitian ini yaitu 
pentingnya pola asuh makan yang baik dan benar, sehingga diharapkan kedepannya tidak ada lagi anak yang terkena stunting.

\section{METODE PENELITIAN}

\section{Tahapan Penelitian}

Tahapan penelitian meliputi : persiapan, observasi, pengurusan ijin penelitian, pengambilan data awal, pelaksanaan penelitian dan pelaporan penelitian.

\section{Desain Penelitian}

Dalam melaksanakan penelitian ini, desain penelitian yang dilakukan adalah penelitian deskriptif analitik dengan menggunakan metode cross sectional dengan uji analisis Chi Square. Penelitian ini mengukur pengaruh pola asuh makan terhadap derajat stunting anak balita di Kabupaten Indramayu. Uji Chi Square digunakan untuk menguji hubungan atau pengaruh dua buah variabel nominal dan mengukur kuatnya hubungan antar variabel $(\mathrm{C}=$ Coefisien of contingency).

\section{Lokasi Penelitian}

Penelitian ini dilakukan di dua belas desa yang ada di Kabupaten Indramayu yang terdiri dari desa Balongan, Rawadalem, Sudimampir Lor, Tegalurung, Pringgacala, Lemah Ayu, Tenajar Kidul, Kalianyar, Tunggul Payung, Kiajaran Wetan, Totoran, dan Kerticala. Lokasi penelitian ini merupakan lokus stunting, maka dari itu peneliti mengambil lokasi tersebut sebagai lokasi penelitian.

\section{Populasi dan Sampel Penelitian}

\section{Populasi}

Populasi dalam penelitian ini seluruh balita stunting yang berada diwilayah Balongan, Rawadalem, Sudimampir Lor, Tegalurung, Pringgacala, Lemah Ayu, Tenajar Kidul, Kalianyar, Tunggul Payung, Kiajaran Wetan, Totoran, dan Kerticala.

\section{Sampel}

Diperoleh dengan rumus sebagai berikut : $:^{[15]}$

$$
\begin{aligned}
& n=\frac{N}{1+N \cdot d^{2}} \\
& \text { Keterangan : } \\
& \mathrm{N}=\text { besar populasi } \\
& \mathrm{n}=\text { jumlah sampel } \\
& \mathrm{d}=\text { tingkat kepercayaan/ ketepatan yang diinginkan }
\end{aligned}
$$
sebesar 5\% 
Dengan perhitungan sebagai berikut :

$$
\begin{aligned}
n & =\frac{4135}{1+4135(0.05)} 2 \\
n & =\frac{4135}{10,34} \\
n & =399,9 \\
& =400
\end{aligned}
$$

Berdasarkan hasil perhitungan di atas, maka jumlah sampel dalam penelitian ini adalah 400-anak balita yang stunting.

\section{Teknik Pengumpulan Data}

Penentuan sampel dalam penelitian ini menggunakan teknik non-probability sampling dengan cara purposive sampling. Metode purposive sampling yaitu teknik penentuan sampel yang berdasarkan pada pertimbangan tertentu yang dibuat oleh peneliti. Jenis data yang digunakan dalam penelitian ini yaitu data primer dan sekunder. Peneliti melakukan pengumpulan data dengan cara wawancara menggunakan kuesioner.

\section{Analisis Data}

\section{Analisis Univariat}

Analisis ini dilakukan secara deskriptif dengan distribusi frekuensi variabel untuk kategori dari masing-masing variabel yang diteliti, baik variabel independen maupun variabel dependen. Analisis univariat bermanfaat untuk melihat gambaran data yang dikumpulkan dan apakah data sudah optimal untuk dianalisis lebih lanjut.

\section{Analisis Bivariat}

Analisis data yang digunakan dalam penelitian ini adalah analisis bivariat yang dilakukan terhadap dua variabel yang diduga berhubungan..Analisis uji statistik yang digunakan pada penelitian ini yaitu menggunakan chi square untuk menguji pengaruh pola asuh makan dengan derajat stunting. Pendekatan waktu yang digunakan yaitu cross sectional, yaitu suatu penelitian yang mempelajari hubungan antara faktor risiko dengan faktor efek yang dilakukan observasi atau pengukuran variabel sekali dan sekaligus pada waktu yang sama (Notoatmodjo, 2010). 


\section{HASIL PENELITIAN DAN PEMBAHASAN}

Hasil Analisis Univariat dan Bivariat Pola Asuh Makan kaitannya dengan Derajat Stunting

Tabel 1. Frekuensi Derajat Stunting

\begin{tabular}{lcc}
\hline Derajat Stunting & Frekuensi & \% \\
\hline Ringan & 159 & 39,8 \\
Sedang & 241 & 60,2 \\
Total & 400 & 100 \\
\hline
\end{tabular}

Berdasarkan tabel 1 dapat dilihat bahwa sebagian besar responden dengan derajat stunting yang sedang yaitu sebanyak 60,2\%. Stunting merupakan gagalnya proses adaptasi psikososial pada fisiologis pertumbuhan diakibatkan penyebab utamanya yaitu asupan gizi yang tidak adekuat terutama asupan mineral (kalsium, posfor, magnesium, stanum, zinc, zat besi), vitamin A dan protein serta respon terhadap infeksi berulang dan terus menerus (Kurniawati T, 2017)

Tabel 2. Frekuensi Pola Asuh Makan

\begin{tabular}{lll}
\hline Pola Asuh & Frekuensi & \% \\
\hline Baik & 182 & 45,5 \\
Kurang Baik & 218 & 54,5 \\
Total & 400 & 100 \\
\hline
\end{tabular}

Berdasarkan tabel 2 dapat dilihat bahwa sebagian besar responden memiliki pola asuh makan yang kurang baik yaitu sebanyak 54,5\%. Pola asuh makan yang diterapkan oleh ibu akan berpengaruh terhadap pertumbuhan dan perkembangan balita karena kekurangan gizi pada masa balita akan bersifat irreversible (tidak dapat pulih), sehingga pada masa ini balita membutuhkan asupan makan yang berkualitas (Martianto D, 2011). Jika dilihat gambaran pola asuh makan di tempat penelitian terlihat bahwa masih banyak ibu yang memiliki pola asuh makan yang kurang baik.

Penyajian makanan untuk balita diperlukan kreatifitas ibu agar makanan terlihat menarik sehingga dapat menimbulkan selera makan anak balita. Penyajian makanan yang akan diberikan kepada anak balita harus memperhatikan porsi atau takaran konsumsi makan serta frekuensi makan yang dianjurkan dalam sehari sehingga tidak terjadi defisit atau kelebihan energi yang pada akhirnya akan mempengaruhi status gizi anak. 
Tabel 3. Hubungan Pola Asuh Makan dengan Derajat Stunting

\begin{tabular}{|c|c|c|c|c|c|}
\hline Derajat & & & uh Makan & & P-Value \\
\hline Stunting & Baik & $\%$ & Kurang Baik & $\%$ & \\
\hline Ringan & 88 & 48,4 & 71 & 32,6 & \\
\hline Sedang & 94 & 51,6 & 147 & 67,4 & \\
\hline Total & 182 & 100 & 218 & 100 & 0.001 \\
\hline
\end{tabular}

\section{PEMBAHASAN}

Penyebab stunting yaitu rendahnya angka sosial ekonomi, pola asuh makan, intake zat gizi, kebijakan negara, dan sebagainya (Masrul, 2018). Hasil penelitian ini diperkuat dengan penelitian yang dilakukan oleh Novita bahwa ada hubungan yang bermakna antara pola asuh makan dengan kejadian stunting (Novita, 2018).

Pola asuh makan adalah cara makan seseorang atau sekelompok orang dalam memilih makanan dan memakannya sebagai tanggapan terhadap pengaruh fisiologi, psikologi budaya dan sosial (Waryana, 2010). Pola asuh terhadap anak dimanifestasikan dalam beberapa hal berupa pemberian ASI dan makanan pendamping, rangsangan psikososial, praktek kebersihan/hygiene dan sanitasi lingkungan, perawatan anak dalam keadaan sakit berupa praktek kesehatan di rumah dan pola pencarian pelayanan kesehatan (Panjaitan, 2011). Untuk kebutuhan pangan/gizi balita, ibu menyiapkan diri sejak prenatal dalam mengatur dietnya selama kehamilan, masa neonatal berupa pemberian Air Susu Ibu (ASI), menyiapkan makanan tambahan berupa makanan padat yang lebih bervariasi bahannya atau makanan yang diperkaya, dan dukungan emosional untuk anak (Kartini, 2006).

Febriani dalam penelitiannya mengatakan bahwa pola asuh dalam keluarga berupa kebiasaan pemberian makan, kebiasaan pengasuhan, kebiasaan kebersihan dan kebiasaan mendapatkan pelayanan kesehatan berhubungan dengan kejadian stunting balita. Permasalahan gizi balita stunting tidak mutlak terjadi pada keluarga miskin tetapi lebih disebabkan oleh peranan pola asuh yaitu kebiasaan pemberian makan, kebiasaan pengasuhan, kebiasaan kebersihan dan kebiasaan mendapatkan pelayanan kesehatan yang baik 
dalam keluarga miskin yang dapat mengurangi kecenderungan balita untuk mengalami stunting (Febriani, 2019)

\section{KESIMPULAN}

Kejadian stunting dengan derajat stunting sedang lebih banyak dibandingkan dengan derajat stunting ringan yaitu sebanyak 60,2\%. Pola asuh makan kurang baik lebih banyak dibandingkan dengan pola asuh makan baik yaitu sebanyak $54,5 \%$. Terdapat hubungan yang bermaknapola asuh makan dengan derajat stunting dengan (P-Value 0,001).

\section{DAFTAR PUSTAKA}

Bella, F. D., Fajar, N. A., \& Misnaniarti, M. Hubungan pola asuh dengan kejadian stunting balita dari keluarga miskin di Kota Palembang. Jurnal Gizi Indonesia (The Indonesian Journal of Nutrition), 8(1), 31-39.

Jafar N, dkk. 2012. Modul pelatihan edukasi makanan pendamping Air Susu Ibu (MP-ASI).

Kartini A, dkk. Kejadian Stunting dan Kematangan Usia Tulang pada Anak Usia Sekolah Dasar di Daerah Pertanian Kabupaten Brebes. Jurnal Kesehatan Masayarakat Vol 11 No 2 Januari 2016.

Kurniawati, T. 2018. Langkah-Langkah Penentuan Sebab Terjadinya Stunting Pada Anak. Pedagogi: Jurnal Anak Usia Dini dan Pendidikan Anak Usia Dini, 3(1), 51-63.

Martianto, D., Riyadi, H., \& Ariefiani, R. 2011. Pola asuh makan pada rumah tangga yang tahan dan tidak tahan pangan serta kaitannya dengan status gizi anak balita di Kabupaten Banjarnegara. Jurnal Gizi dan Pangan, 6(1), 5158 .

Masrul, M. 2019. Studi Anak Stunting dan Normal Berdasarkan Pola Asuh Makan serta Asupan Zat Gizi di Daerah Program Penanggulangan Stunting Kabupaten Pasaman, Pasaman Barat. Jurnal Kesehatan Andalas, 8(2S), 7481. 2018

Widyaningsih, N. N., Kusnandar, K., \& Anantanyu, S. 2018. Keragaman pangan, pola asuh makan dan kejadian stunting pada balita usia 24-59 bulan. Jurnal Gizi Indonesia (The Indonesian Journal of Nutrition), 7(1), 22-29.

Panjaitan, R. Pola Asuh Ibu dan Status Gizi Anak Balita di Kecamatan Pollung Kabupaten Humbang Hasundutan Tahun 2011. 
Purwandini, K., \& Kartasurya, M. I. 2013. Pengaruh pemberian Micronutrient Sprinkle terhadap perkembangan motorik anak stunting usia 12-36 bulan (Doctoral dissertation, Diponegoro University).

Hoffman, D. J., Sawaya, A. L., Verreschi, I., Tucker, K. L., \& Roberts, S. B. 2000. Why are nutritionally stunted children at increased risk of obesity? Studies of metabolic rate and fat oxidation in shantytown children from Sao Paulo, Brazil. The American journal of clinical nutrition, 72(3), 702-707.

Profil Dinas Kesehatan Kabupaten Indramayu, 2018

Riset Kesehatan Dasar, 2018

Waryana. Gizi Reproduksi. Yogyakarta: Pustaka Rahima; 2010.

WHO. Nutrition Landscape Information System (NLIS) Country Profile Indicators: interpretation Guide. Switzerland: WHO press 2010. P 1 